\author{
Grzegorz Trębicki \\ ORCID: 0000-0001-6740-8922 \\ Uniwersytet Jana Kochanowskiego w Kielcach
}

\title{
Reframing myth: Essays on mythopoeic fantasy
}

DOI: $10.19195 / 0867-7441.24 .30$

Review: Brian Attebery, Stories about Stories: Fantasy and the Remaking of Myth, Oxford University Press, Oxford-New York 2014, 240 pp.

Słowa kliuczowe: fantasy, literatura niemimetyczna, Brian Attebery, fantastyka

Keywords: fantasy, non-mimetic literature, Brian Attebery

Brian Attebery, professor of English at Idaho State University and editor-inchief of The Journal of the Fantastic in the Arts, is probably the most renowned academic proponent of fantasy as a genre in American criticism. Stories about Stories is his third and most recent venture into this field. ${ }^{1}$ It is also - apart from Marek Oziewicz's One World, One People ${ }^{2}$ — probably the most interesting and profound study of the relationships between fantasy and myth up to date. ${ }^{3}$

The apparently concise introduction proves especially informative from a more synthetic point of view as the observations made there set ground for the discussion of mythopoeic fantasy in a larger literary-theoretical (but also cultural, psychological and sociological) context. Attebery for his own needs defines myth as "any collective story that encapsulates a world view and authorizes belief". ${ }^{4}$ As an example, he mentions Christian myth (essential for such founders of fantasy as J.R.R. Tolkien and C.S. Lewis) which - in this interpretation - includes not only "the creation accounts or flood story from Genesis" or "the cycle of incarnation, atonement, and resurrection from the Gospels" but also, for example, "various medieval embroideries on those, such as the story of Adam's first wife Lilith"

${ }^{1}$ The remaining two being The Fantasy Tradition in American Literature: From Irving to Le Guin (Bloomington 1980) and the seminal Strategies of Fantasy (Bloomington-Indianopolis 1992). See my review of the latter ("The defence of fantasy", Literatura i Kultura Popularna 22, 2016, pp. 153-156).

${ }^{2}$ M. Oziewicz, One Earth, One People: The Mythopoeic Fantasy Series of Ursula K. Le Guin, Lloyd Alexander, Madelaine L'Engle and Orson Scott Card, Jefferson-London 2008. See my review of this study — "Fantasy literature and the twentieth century mythological revival: Marek Oziewicz's 'One World, One People'”, Extrapolation 54, 2013, no. 1, pp. 122-125.

${ }^{3}$ In the context of the mutual relationship between fantasy and myth, two works published in Poland are, perhaps, worth mentioning. The first is Bogdan Trocha's Degradacja mitu w literaturze fantasy (Zielona Góra 2009), the other - my own collection Synkretyzm fantasy. Fantasy świata wtórnego: literatura, kultura, mit (Kraków 2014).

${ }^{4}$ B. Attebery, Stories about Stories: Fantasy and the Remaking of Myth, Oxford-NewYork 2014 , p. 2. All quotes below will come from this edition. Page numbers are given in brackets. 
(p. 2). Having said that, he immediately notices that " $[t]$ he problem for literalists is not that fantasy denies Christian myths but that it rearranges, reframes, and reinterprets them" (p. 2). Fantasy, Attebery argues, "is fundamentally playful [...] Its way of playing with symbols encourages the reader to see meaning as something unstable and elusive, rather than single and self-evident" (p. 2).

Attebery, then, is not so interested in finding mythical elements in fantasy literature (or cataloguing them) since it is quite obvious that they are there; in fact, he is more concerned about "the way writers use fantasy to reframe myth: to construct new ways of looking at traditional stories and beliefs" (p. 3). Thus, Attebery conludes,

\begin{abstract}
fantasy's main claim to cultural importance resides [...] in the work of redefining the relationship between contemporary readers and mythic texts. It shares that work with such enterprises as depth psychology, religion, and popular media. Unlike those institutions, fantasy claims no authority nor exerts hegemony. It denies its own validity; the one characteristic shared by all fantasy narratives is their nonfactuality. The fundamental premise of fantasy is that the things it tells not only did not happen but could not have happened. In that literal untruth is freedom to tell many symbolic truths without forcing a choice among them (p. 4).
\end{abstract}

The study itself (quite similarly to Strategies of Fantasy) is to a large extent more of a collection of studies than a monograph exploring a single issue at depth. ${ }^{5}$ The first part of the book is mainly historical and documents the successive stages on the road to modern mythopoeic fantasy. Thus, chapter 1 - "Fantasy as a route to myth" - follows the story of the "emergence of fantasy as a mode which is also the story of the scholarly discovery of myth" (p. 5). Chapter 2- "Make it old: The other mythic method" — is dedicated to the generation of the Inklings. Here, apart from Lewis and Tolkien such writers as E.R. Eddison, Lord Dunsany, P.L. Travers or James Branch Cabell are also discussed. Chapter 3 - "Silver lies and spinning wheels" - is devoted specifically to George McDonalds' and C.S. Lewis's reworkings of Christian myth. Finally, in chapter 4 - "Romance and formula, myth to memorate" - Attebery moves to more recent literary landscapes, focusing on the fantasy boom in the 1950s, 1960s and 1970s. At the same time, he also discusses some critical, psychological and anthropological reactions to both fantasy and myth, referring to the studies of Vladimir Propp, C.W. Sullivan or Joseph Campbell. His observations, albeit brief, are quite insightful. He comments, for example - in my opinion very adequately — on the famous concept of monomyth coined by Campbell, stating that "the problem with [...] monomyth as an analytical tool is that it always works because it simplifies every story to the point where nothing but the monomyth is left" (p. 108).

Chapter 5 - "Expanding the territory: Colonial fantasy" - examines what Attebery calls "cosmopolitan fantasy", that is, works based on lore and mythical traditions other than Judeo- Christian. His central example is "Patricia Wrightson,

${ }^{5}$ In fact, a lot of the material has been published previously elsewhere in the form of single articles. 
who was first hailed as a sympathetic translator of Aboriginal myth into modern fantasy and later condemned as an exploiter and cultural appropriator" (p. 6).

In chapter 6 - "Angels, fantasy and belief" - Attebery returns to Judeo-Christian myth again, analyzing the motif of angels not only in fantasy books but in contemporary popular culture in general.

Chapter 7 - "The postcolonial fantastic" - in a way continues some of the issues raised in chapter 5, but this time the global context is viewed "from the perspective of the formerly colonized rather than the colonizers" (p. 7). The focus is on the writers such as Nalo Hopkinson, Amitav Ghosh or Leslie Marmon Silko for whom "the fantastic becomes a way to represent the inevitable double vision of those who are both inside and outside Western and Modern culture" (p. 7).

Finally, in chapter 8 - "Coyote's eyes: Situated fantasy" - Attebery looks "at writers who have used the fantastic to challenge the binaries of modern/primitive and self/other [...] reflecting postmodernism's self-consciousness about storytelling and employing its typical disruptions of genre and violations of textual boundaries" (p. 8). Here novels of Alan Garner, Jeanne Larsen, Molly Gloss, and Ursula K. Le Guin are discussed at some length.

The collection includes also two, as Attebery calls them, "interludes" — short essays that function like asides of his main argument which follows other facets of mythopoeic fantasy. The first — "Taxonomic interlude: A note on genres" returns to the problems already partly signalled in Strategies of Fantasy, that is confusion and misinterpretation raising from categorization of texts. In the second — "Literalist interlude: Burning Harry Potter" - Attebery offers a cultural and sociological rather than literary analysis, pondering on religious fundamentalists' responses to fantasy. ${ }^{6}$

Attebery's study may not be immensely systematic but it is definitely brilliant and cognitive. His essayistic style is, as usual, engaging, relatively easy to follow and free of scholarly jargon, which makes the study accessible even for a nonacademic (albeit ambitious and educated) reader. For scholars interested in fantasy, especially in its mythopoeic variation, this is (similarly to Strategies of Fantasy), quite predictably, an obligatory reading.

\section{Bibliography}

Attebery B., Stories about Stories: Fantasy and the Remaking of Myth, Oxford University Press, Oxford-New York 2014.

Attebery B., Strategies of Fantasy, Indiana University Press, Bloomington-Indianopolis 1992.

Attebery B., The Fantasy Tradition in American Literature: From Irving to Le Guin, Indiana University Press, Bloomington 1980.

${ }^{6}$ The subject might prove especially interesting for the Polish reader, as the Harry Potter saga raised a lot of controversy also in our country. 
Oziewicz M., One Earth, One People: The Mythopoeic Fantasy Series of Ursula K. Le Guin, Lloyd Alexander, Madelaine L'Engle and Orson Scott Card, McFarland \& Company, Jefferson-London 2008.

Trębicki G., "Fantasy literature and the twentieth century mythological revival: Marek Oziewicz's 'One World, One People"', Extrapolation 54, 2013, no. 1, pp. 122-125.

Trębicki G., Synkretyzm fantasy. Fantasy świata wtórnego: literatura, kultura, mit, Libron, Kraków 2014.

Trębicki G., "The defence of fantasy (Review: Brian Attebery, Strategies of Fantasy, Indiana University Press, Bloomington and Indianopolis 1992)", Literatura i Kultura Popularna 22, 2016, pp. $153-156$.

Trocha B., Degradacja mitu w literaturze fantasy, Wydawnictwo Uniwersytetu Zielonogórskiego, Zielona Góra 2009. 